\title{
Pequi Fruit (Caryocar brasiliense) in Minas Gerais: Commercialization and Public Policy
}

\author{
Luiza Helena Pedra da Silva ${ }^{1}$ (i) 0000-0001-6972-1429 \\ Lorena Cristina Lana Pinto ${ }^{2}$ (1) 0000-0003-2109-6171 \\ Sarah Alves de Melo Teixeira ${ }^{3}$ (1) 0000-0002-5029-3855 \\ Maria Auxiliadora Drumond ${ }^{3}$ (10) 0000-0002-0677-6673
}

\begin{abstract}
Extractivism of pequi (Caryocar brasiliense) fruit represents an economic opportunity for rural communities of Brazil despite the lack of research on its production chain. This study aims to characterize the commercialization of pequi fruit in municipalities of the state of Minas Gerais and identify public policies that strengthen its production chain in order to support its use for generating income within rural communities. Information was obtained through searches on official sites, published literature and other documents, and through semi-structured and open interviews held in 39 commercial establishments and in five restaurants. Between 2003 and 2011, the national production and the price of one tonne of pequi has risen from $42 \%$ to $209 \%$. Sales of pequi by the Centrais de Abastecimento de Minas Gerais S.A. (CeasaMinas) of Greater Belo Horizonte, Brazil, has risen 113\% between 2010 and 2014. The results indicate the feasibility of pequi extractivism for a quilombola community.
\end{abstract}

Keywords: production chain, hotspot, income, quilombo.

\section{INTRODUCTION}

The current emphasis towards non-timber forest products (NTFPs) is mainly due to the effort to harmonize economic development, conservation and the maintenance of rural communities in their territories (Dembner, 1991; Wadt et al., 2008). These products can contribute to the social inclusion of local groups in the face of pressure on socio-biodiversity by commodity production (Becker, 2001; Ticktin, 2004). Profits obtained with NTFPs extractivism may be greater than that from activities that involve the removal of native vegetation, such as agribusiness (Arnold \& Ruiz-Pérez, 2001; Peters et al., 1989). Moreover, the economic use of NTFPs may reduce pressure for the deforestation of natural areas and, at the same time, generate income for local communities (Adams et al., 2013; Enders et al., 2006; Marshall \& Newton, 2003; Schmidt et al., 2007; Wickens, 1991).

Pequi, Caryocar brasiliense Cambess., is a typical fruit of the Cerrado biome, an important hotspot for the conservation of global biodiversity (Myers et al., 2000), and it is an important socio-biodiversity resource for generating work and income for local communities, representing a path for local development, when the production is carried out in a sustainable way (Afonso, 2012; Aquino et al., 2008; Avidos \& Ferreira, 2000;
Felfili et al., 2004). In the state of Minas Gerais (MG), the Northern region cities have the highest production in pequi due to, among other factors, the organization of extractivists into associations and cooperatives, which are few or nonexistent in other regions (IBGE, 2010; Rezende \& Cândido, 2014). Moreover, the implementation of the National Plan for the Promotion of Socio-Biodiversity Product Chains (PNPSB) in April 2009 strengthened the production chain of pequi in MG (Afonso, 2012).

Pequi is sold as fruit in natura, or as nuts, liqueur, oil, candy, pickled pulp, cream and soap, among others forms. The production of these items, their recipes and the ways they are used often originate from the experience of local communities. In MG, extractivism, processing and commercialization of the Cerrado fruits, especially pequi, are alternative sources of income for many rural communities. These activities are generally informal, which limits the amount of information available on the production chain of pequi in the region (Rezende \& Cândido, 2014).

The richness of Cerrado is associated with great sociocultural diversity, represented by traditional communities and family farmers that have knowledge about the handling and the preservation of biodiversity (Nogueira \& Fleischer, 2005; Silva, 2009). One kind of community in Brazil is called "quilombo". Quilombos were formed by descendants of

\footnotetext{
${ }^{1}$ Universidade Federal dos Vales do Jequitinhonha e Mucuri (UFVJM), Diamantina, MG, Brasil

${ }^{2}$ Instituto Interdisciplinar de Estudos e Pesquisas em Sustentabilidade (Instituto Sustentar), Brumadinho, MG, Brasil

${ }^{3}$ Universidade Federal de Minas Gerais (UFMG), Belo Horizonte, MG, Brasil
} 
escaped black slaves who mostly live in rural areas and had specific territorial relationships and resisted in spite of historical oppression (ITESP, 2000).

In the municipality of Paraopeba there is a quilombola community named Pontinha, whose main economic activity is the giant earthworm extraction ("minhocuçu", Rhinodrilus alatus), which occurs mainly during its estivation period in the dry season (Drumond et al., 2013; Drumond et al., 2015). Pequi is abundant in the territory of this quilombo, where it fruits during the rainy season, a period that overlaps with the reproductive period of the "minhocuçu". Thus, the extraction and processing of this fruit may provide an alternative source of income for the Pontinha community (Pinto et al., 2016). However, for this to occur, the mode of insertion of these products into the market must first be identified.

Hence, the aim of this study was to characterize the commercialization and use of pequi in the region where Pontinha is located, and to study the main public policies that promote the production chain of pequi in MG and Brazil.

\section{MATERIALS AND METHODS}

\subsection{Production chain and public policy}

Information about the current scenario of extractivism, processing, commercialization, and public policy related to pequi (Caryocar brasiliense) in MG was obtained from research presented in papers, reports, relevant legislation, technical documents, bulletins, and booklets. Access to academic work was accomplished by searches on Portal Capes, SciELO, and Google Scholar databases, using keywords such as "extrativismo de pequi", "uso comercial de pequi", "trabalho e pequi", "renda e pequi", "cadeia produtiva do pequi", "cooperativismo e pequi", "cooperativas e pequi", "associações e pequi" e "comercialização de frutos do Cerrado".

\subsection{Commercialization in the Central Region and Belo Horizonte Metropolitan Region of Minas Gerais}

A total of 39 commercial establishments were selected from locations near Pontinha quilombola community, located in the municipalities of Belo Horizonte Metropolitan Region of Minas Gerais: Sete Lagoas, Paraopeba, Caetanópolis, Belo Horizonte $(\mathrm{BH})$, and Contagem; and in the Central Region of Minas Gerais: São José da Lagoa, a district of the municipality of Curvelo (Figure 1). The establishments were selected in a non-probabilistic way and followed the snowball methodology (Bailey, 2008), according to which, after the first location was visited, other mentioned establishments that sold pequi and its products, were sampled.

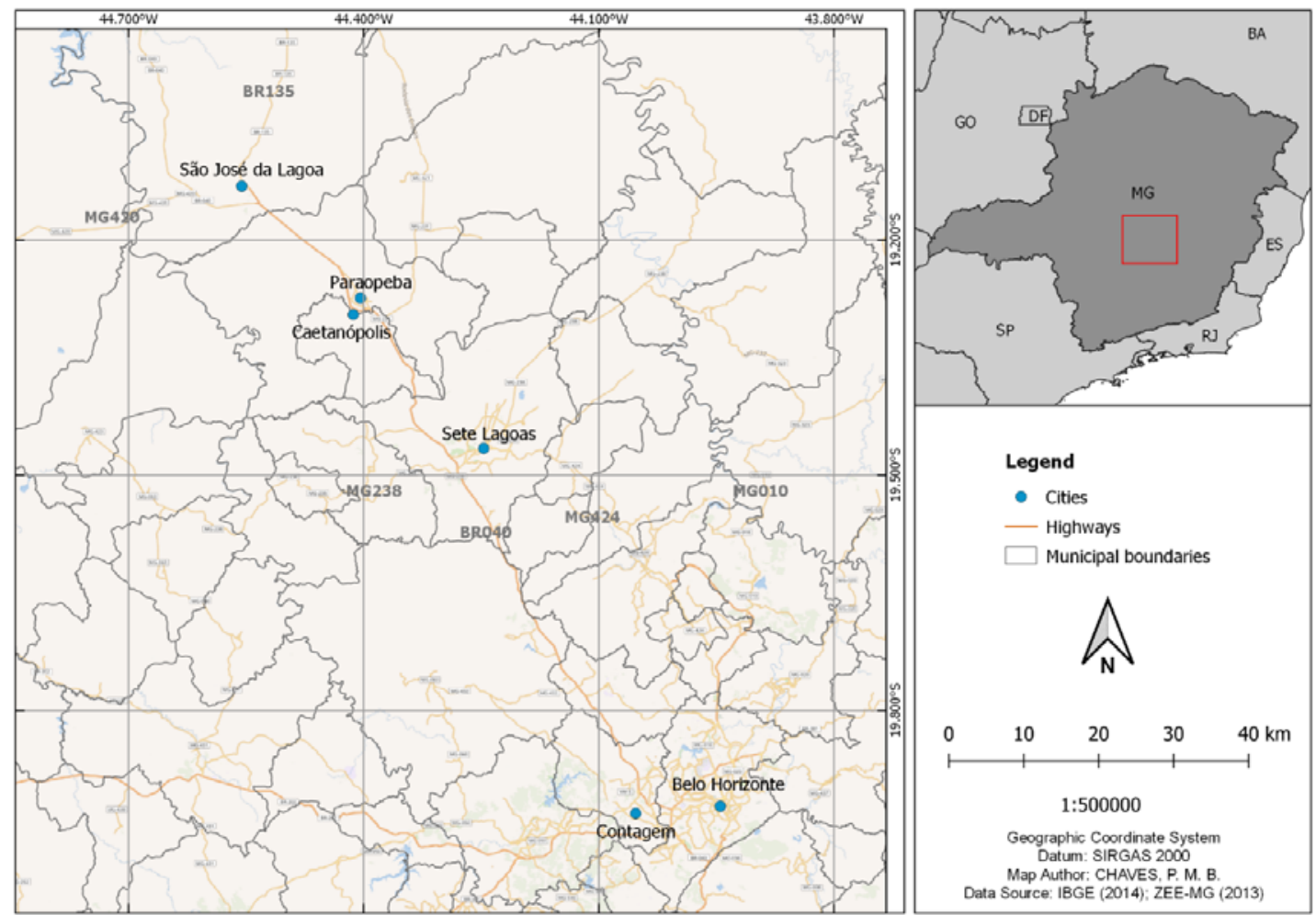

Figure 1. Locations of Pontinha quilombola community and municipalities where commercial establishments that sell pequi and its products were investigated. 


\subsection{Consumption of pequi in restaurants}

Given the possibility of potential market niches for the sale of pequi, and the proximity of the Pontinha quilombola community, restaurants in $\mathrm{BH}$, the capital of MG, where pequi and its products have had culinary use were also surveyed. These establishments were found by research using the websites GuiaMais (www.guiamais.com.br/belo-horizonte-mg), Veja BH (vejabh.abril.com.br), and Agenda BH (www.agendabh.com.br).

\subsection{Data collection and analysis}

Information on the commercialization of pequi and its products in commercial establishments in the Central Region and Belo Horizonte Metropolitan Region of Minas Gerais was obtained through semi-structured and open interviews made between October 2013 and March 2014. The interviews were carried out preferably with the owners and managers of the establishments, but if they were not available the interviews were held with other members of the staff. Measure units of sales (liter, kilogram, unit), amount sold (harvesting and off-season), purchase and sale prices, product origin, and the most-wanted items were surveyed. Analysis of the pequi commercialization of pequi in the Minas Gerais Supply Center (CeasaMinas) of Greater Belo Horizonte was emphasized due to its relevance to the commercialization and supply of fruits to $\mathrm{BH}$ and surrounding areas.

Surveys of restaurants in $\mathrm{BH}$ were accomplished by interviews regarding the pequi products consumed (pit, oil, cream, sauce, among others), sales price, quantity, origin, frequency of sales, demand and dishes offered, and any possible difficulties in acquiring the product.

The data collected were described quantitatively, and also it were analyzed qualitatively through classification of material in parts, identification of convergences and search for patterns and trends, according to Lüdke \& André (1986).

\section{RESULTS AND DISCUSSION}

\subsection{Dynamics of the commercialization of pequi and its subproducts}

The data made available by the Instituto Brasileiro de Geografia e Estatística (IBGE), showed growth in the amount of pequi (pit) marketed in Brazil and the price charged from 2003 to 2011 (Figure 2). National production of pequi increased $43 \%$ in this period, rising from 4,941 tonnes to 7,047 tonnes. The price of one tonne of pequi had an even greater change, increasing $209 \%$, rising from $R \$ 3,601.00$ in 2003 to $\mathrm{R} \$ 11,113.00$ in 2011 (IBGE, 2011).
According to the 2011 Production of Vegetal Extraction and Silviculture report, the states of Ceará and Minas Gerais made the greatest contributions to the national production of pequi (pit), representing $61 \%$ (4,281 tonnes) and 25\% (1,776 tonnes), respectively (IBGE, 2011). In 2010, MG was responsible for $29.7 \%$ ( $R \$ 1,068,800.00)$ of the national production. The North Region of MG produced 73\% $(1,318$ tonnes) of the pequi commercialized in the state, followed by the Belo Horizonte Metropolitan Region, with $23 \%$ of the production (397 tonnes), and the Jequitinhonha Valley Region, with 0.6\% (10 tonnes) (IBGE, 2010; Rezende \& Cândido, 2014). These data might be urderestimated since extractivism and commercialization of pequi are primarily performed informally and, therefore, sales are under-reported in official records (Rezende \& Cândido, 2014). Thus, it is essential to obtain information about the commercialization of pequi in the microregions where it is produced in order to establish plans and actions to improve its production chain (Oliveira et al., 2017).

The production chains for pequi vary among regions of MG (Rezende \& Cândido, 2014), since the fruits are collected in pastures and fragments of Cerrado in a collector's property, in common use areas, in leased lands, or in non-leased thirdparty lands (Cândido et al., 2012). The commercialization of pequi in $M G$ is accomplished through distinct channels, the most common of which are: a) Short or Direct Chain direct commercialization between farmers and consumers, as in free markets and via microlocal and direct sales; b) Smooth Integration Chain - commercialization structures that are created or managed by agro-extractivists themselves, often with the help of institutions or companies that seek fair trade in search of regional or national channels; and c) Oligopsonic Market - few buyer companies or wholesalers dictate the rules, thus making extractivists vulnerable (Freitas \& Ribeiro, 2013).

In addition to sales of fruit in natura, pequi may be sold as dehydrated pulp, pickled pulp, flour, dehydrated nuts (natural, salty or caramelized), cream, frozen pit or pulp, and liqueur, or for uses related to cosmetics (Carrazza \& Ávila, 2010; Carrazza \& Figueiredo, 2010). Pequi is also used in the manufacturing of popsicles, ice cream, and condiments. Moreover, its products are often offered during coffee breaks, as cocktails, and as part of refined cuisine (José, 2007). Increasing demand for other sociobiodiversity products has also been documented, such as for the production chains of baru (Dipteryx alata), babaçu (Attalea spp.) and buriti (Mauritia spp.), all of which have generally been associated with strengthening production chains and appreciation for native products (Afonso et al., 2015; Magalhães, 2014). 


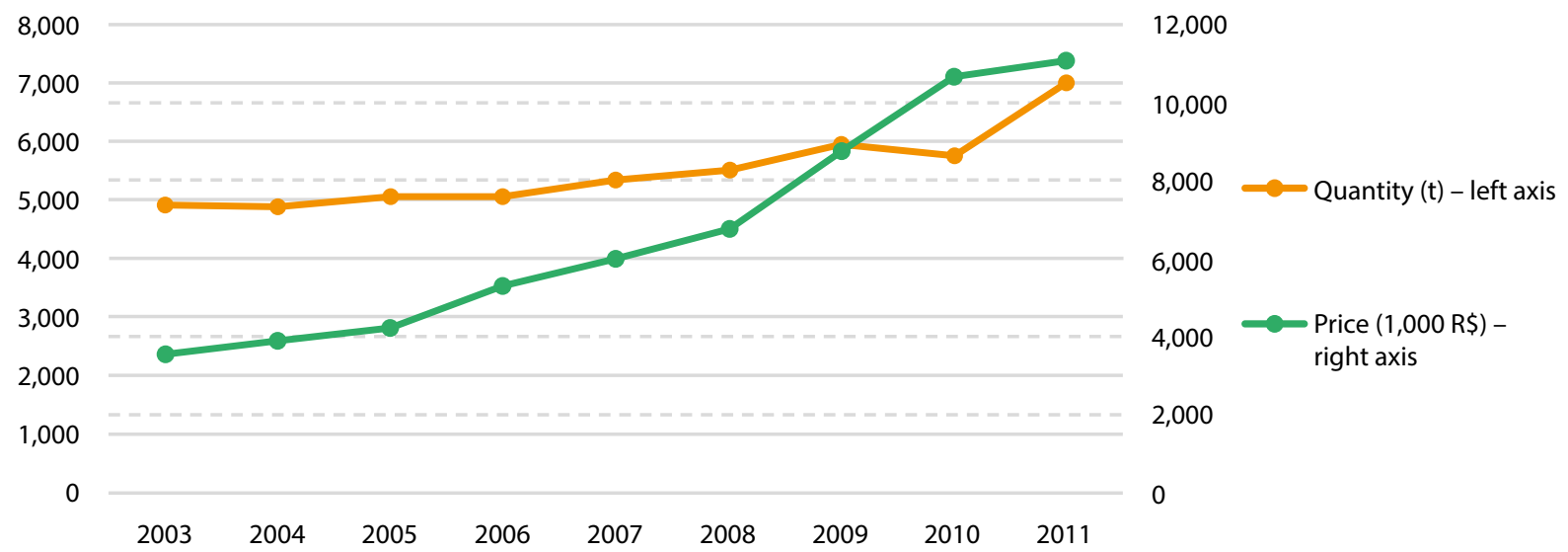

Figure 2. Quantity $(t)$ in tonnes, and price $(\mathrm{R} \$)$ in Reais $(\mathrm{R} \$ 1,000.00)^{\star}$, for pequi (pit) commercialized in Brazil from 2003 to 2011.

Source: IBGE (2011).

* Average conversion between 2003 and 2011: R\$ $1.00=$ US\$2.20.

Some pequi extractivists work under a family-farming regimen, either individually or along with businesses of solidarity economy (Aquino et al., 2008; Cândido et al., 2012). The majority of pequi is sold in natura, while the remainder is processed at home by the collectors, or benefaction units and cooperative agroindustries (Cândido et al., 2012). As an opportunity to increase economic earnings, auto-management and fairer work relationships are factors that stimulate the creation of cooperatives and associations (Crúzio, 2001). According to Cândido et al. (2012), prospecting for pequi and other fruits of the Cerrado in the Northern MG is carried out through cooperativism, which absorbs the workforce of rural workers.

\subsection{Public policies for the promotion of extractivism and commercialization of pequi}

Currently, there are various initiatives that strengthen the production chain of pequi and other Cerrado fruits, although they have isolated impacts without structural changes in food production. Given that many extractivists belong to traditional communities, the National Policy for Traditional Peoples and Communities (Brasil, 2007) can guarantee them access to natural resources and inclusion in production, and promote sustainable technologies related to pequi processing. The National Plan for Promotion of Socio-Biodiversity Product Chains (PNPSB) aims to develop integrated actions to strengthen socio-biodiversity production chains by aggregating value and consolidating sustainable markets (Brasil, 2009a).

The Lowest Price Guarantee Policy for products of socio-biodiversity (PGPM Bio) establishes a lowest price per kilogram of pequi through a subvention mechanism that works directly with the extractivist producer (Brasil, 2009c), so that if the market price is lower than that established by Companhia Nacional de Abastecimento (Conab), the producers will not have their product debased. This intervention also helps with the conservation of the Cerrado biodiversity, because it provides a guaranteed income for the harvesting and commercialization of NTFPs. Although this policy may have limiting issues, such as the difficulty for the emission of invoices by the extractivists, it remains a mechanism that allows the sale of an extractivist's product in natura for a minimally fair price, thereby favoring its distribution to selling locations.

Through the Direct Purchase of Family Agriculture with Simultaneous Donation initiative established by the Food Acquisition Program (PAA), and regulated by Federal Ordinance 7,775 (Brasil, 2012), agro-extractivist production is acquired by the Federal Government and donated to public organizations. Furthermore, through the Support to Stock Formation by Family Farming initiative, also by the PAA, financial support is provided for organizations of family farmers to keep food stocks. In the Northern MG, most of the pequi pulp production of cooperatives is bought through this program and reverted into school meals, or provided to daycares, military units, hospitals, and senior citizen homes (Cândido et al., 2012).

The National School Feeding Program (PNAE) (Brasil, 2009b) requires public schools to acquire food from family farms, with a minimum of $30 \%$ of the resources provided by the National Fund for Education Development. Since 2001, the National Program for the Strengthening of Family Farming (Pronaf) has granted rural credit for family farmers individually or collectively (Brasil, 2001a, 2001b). This opportunity for credit allows the optimization of the entire 
chain of the pequi production, since these farmers can plan for the cost of their crop and improve their agro-industrial activity. Examples include investments in equipment or infrastructure for production and commercialization, which result in better-quality products to the consumer market. The availability of credit, by Pronaf simultaneously with the Family Farming Price Guarantee Program (PGPAF), allows a farmer to maintain the productive rhythm of their activities, while being assured of remuneration for production costs given the economic dynamism of the business (Brasil, 2001a, 2006).

The Minas Gerais government also officially acknowledges Local Productive Arrangements of Pequi (LPA of Pequi) (Minas Gerais, 2006). These LPAs make access to lines of credit easier, with lower interest rates, as well as commercialization in internal and external markets, thus developing and mastering technologies, which aggregate higher value to pequi.

Minas Gerais's Program of Incentive for the Harvest, Extraction, Consumption, Commercialization, and Transformation of Pequi and other Native Fruits and Products of the Cerrado (Pró-Pequi), Law 13,965 (Minas Gerais, 2001) - has as one of its objectives the provisioning of support to cooperatives and associations in MG that use pequi. Many of these businesses benefit from actions of "Núcleo do Pequi", a network formed by cooperatives and agro-extractivist associations in the North Region of Minas Gerais that hold a position in the Pro-Pequi State Council. Finally, there are other programs that also benefit agro-extractivists, family farmers and cooperatives in the sector.

\subsection{Commercialization of pequi in the Belo Horizonte Metropolitan Region and the Central Region of Minas Gerais}

The 39 establishments surveyed included open and closed market stands, grocery stores, small markets, supermarkets, supply centers, and city markets (Table 1). The pequi products sold include fruit in natura (with and without skin), pickled pequi (pit and pulp), liqueur, oil, cream, candy, sauce and flour. There is greater demand for in natura fruit $(\mathrm{n}=28)$, followed by oil $(\mathrm{n}=14)$, pickled pit $(\mathrm{n}=12)$, and pulp $(\mathrm{n}=12)$. Most establishments sell more than one kind of product, with those inside the Central Market of Belo Horizonte having the widest variety. The amount of products commercialized differs throughout the year, which is also related to the size and location of the businesses. There are other products made from pequi, such as dehydrated nuts (salty or sweet), extracted nut oil, and pequi pulp with sun-dried meat, which, despite not being sold at the aforementioned establishments, has market potential and may be found at other locations (Afonso et al., 2015).

In natura pequi is purchased from extractivists and sellers in the Belo Horizonte Metropolitan, Central and North regions of Minas Gerais. CeasaMinas is an important provider of pequi to other establishments. The purchase of fruits from the North Region of Minas Gerais may be associated with the fact that the harvest in this region starts in November (Leite et al., 2006), which is prior to the harvest in the Central Region of Minas Gerais, and also with the higher quality of these fruits when compared to others (Afonso et al., 2015). The fruits sold in stands in the district of São José da Lagoa are always collected by extractivists in fragments of Cerrado and pastures located next to their homes.

The units of measure used in the sale of pequi pit are diverse, and include liter, tray, $\mathrm{K}$ box, plate and bowl, which makes it difficult to compare establishments. All establishments have the option to buy pequi (with skin) in $\mathrm{K}$ boxes (a wooden box measuring $495 \mathrm{~mm}$ long, $355 \mathrm{~mm}$ wide and $220 \mathrm{~mm}$ high, according to Luengo et al. (2003), for later commercialization on styrofoam trays with smaller portions). In CeasaMinas, trays containing from 12 to 17 pits were sold for between $\mathrm{R} \$ 0.80$ and $\mathrm{R} \$ 4.00$ each, with a $500 \%$ price reduction during the harvest. Only the stands in São José da Lagoa kept the price for a tray $(\mathrm{R} \$ 5.00)$ constant throughout the harvest (Table 2).

Pequi oil is the most wanted processed pequi product in the establishments surveyed. It is sold in glass or plastic bottles, and usually in $150 \mathrm{~mL}, 1 \mathrm{~L}$, and $2 \mathrm{~L}$ units. In São José da Lagoa, as well as in Caetanópolis, $150 \mathrm{~mL}$ can cost $\mathrm{R} \$ 15.00$ - twice the price found in the markets of Sete Lagoas. This difference may be due to the larger production scale in Sete Lagoas than in São José da Lagoa, where there are few producers of pequi oil because it is an entirely artisanal activity. Thus, pure oil supply is small and the price is high. According to the people surveyed, the high quality of the pure oil is the reason for the great amount of sales. Some stands in São José da Lagoa sell up to eight bottles $(150 \mathrm{~mL})$ every day, with an average price of $R \$ 12.00$ they may earn $\mathrm{R} \$ 96.00$ daily just from the sales of this specific product. 
Table 1. Municipalities (in italics) where research on pequi products and their commercialization was carried out, and the number of commercial establishments and products commercialized.

\begin{tabular}{|c|c|c|}
\hline Location & Total of establishments & Products commercialized \\
\hline $\begin{array}{l}\text { Contagem - CeasaMinas Greater } \\
\mathrm{BH}\end{array}$ & 4 stands & Fruit in natura, oil, pickled (pit and pulp), flour, and sauce. \\
\hline Sete Lagoas & 7 stands & Fruit in natura, oil, pickled pulp, liqueur, candy, and cream. \\
\hline Paraopeba & $\begin{array}{l}2 \text { markets and } 4 \text { grocery } \\
\text { stores }\end{array}$ & Fruit in natura, oil, liqueur, sauce, and candy. \\
\hline Curvelo (São José da Lagoa) & 5 stands & Fruit in natura, oil, pickled (pit and pulp), cream, liqueur, and sauce. \\
\hline Caetanópolis & $\begin{array}{l}1 \text { candy-maker } \\
5 \text { stands }\end{array}$ & $\begin{array}{l}\text { Candy (creamy or cut in pieces). } \\
\text { Fruit in natura, oil, pickled (pit and pulp), liqueur, and candy. }\end{array}$ \\
\hline \multicolumn{3}{|l|}{ Belo Horizonte } \\
\hline Central Market of Belo Horizonte & 9 stands & Fruit in natura, oil, pickled (pit and pulp), liqueur, flour, candy, and cream. \\
\hline Grocery stores & 2 grocery stores & Fruit in natura. \\
\hline
\end{tabular}

Table 2. Quantity of pequi commercialized on trays with pits weekly, and variation in the cost per tray in reais (R\$), during the 2014 harvest in 39 establishments surveyed.

\begin{tabular}{lccc} 
Establishments & $\begin{array}{c}\text { Number of trays* } \\
\text { sold in one week }\end{array}$ & Price (R\$) & $\begin{array}{c}\text { Minimum and maximum income } \\
\text { in one week (R\$) }\end{array}$ \\
CeasaMinas Greater BH & 2,560 to 4,670 & 0.80 to 4.00 & $2,048.00$ to $18,680.00$ \\
Grocery stores and small markets in Paraopeba & 50 to 100 & 1.50 to 2.50 & 75.00 to 250.00 \\
Markets and open markets in Sete Lagoas & 47 to 94 & 3.00 to 5.00 & 141.00 to 470.00 \\
Central Market of Belo Horizonte & 28 to 914 & 4.00 to 6.00 & 112.00 to $5,848.00$ \\
Supermarkets and grocery stores in Belo Horizonte & 100 to 400 & 2.00 to 4.00 & 200.00 to $1,600.00$ \\
Open market in São José da Lagoa (Curvelo) & 30 to 90 & 5.00 & 150.00 to 450.00 \\
Caetanópolis & No record & 2.00 to 3.00 & - \\
\hline
\end{tabular}

${ }^{*}$ Tray: the number of pits per tray varies from 12 to $22 ;{ }^{* *}$ Quantity calculated from the average number of in natura fruits in a $\mathrm{K}$ box.

\subsection{Pequi commercialization in the Minas Gerais Supply Center (CeasaMinas) in Greater Belo Horizonte}

Pequi commercialization in the CeasaMinas in Greater Belo Horizonte is carried out in the Producer's Free Market (MLP), also known as "Pedra". The MLP is a space for the sale of products from small producers. Only self-produced products can be officially commercialized in MLP, but all interviewees claim to sell products from third parties. The quantity of pequi (pit) sold in CeasaMinas increased progressively from 2010 to 2014 , rising from $222,156 \mathrm{~kg}$ to $474,689 \mathrm{~kg}$, which corresponds to an increase of $114 \%$ (CeasaMinas, [2014?]).

Pequi commercialization in CeasaMinas is concentrated during the fruiting period, between December and February, when a large volume of the marketed pequi is in natura fruit. Pequi commercialization is greatly reduced to non-existent between March and November. The average price per kilogram of pequi with skin in MLP between 2010 and 2014 varied $84 \%$, from $\mathrm{R} \$ 4.69$ (2010) to $\mathrm{R} \$ 8.64$ (2012). The main cities in MG that provided pequi (pit) to CeasaMinas between 2011 and 2014 were Santana de Pirapama and Paraopeba. Paraopeba had the highest contribution to CeasaMinas in
2012. These two cities are in the Belo Horizonte Metropolitan Region and located 60 and $100 \mathrm{~km}$ from Pontinha community, respectively, which makes these cities important locations for the distribution of products made by this community.

The surveyed owners $(n=12)$ of stands in the open markets of São José da Lagoa and Sete Lagoas did not show any interest in selling in natura pequi to CeasaMinas, since transport costs were many times higher than the profit obtained from sales. Moreover, when there is opportunity for sales on a larger scale, the absence of invoice emissions and sanitary regulation become great barriers. Other products are sold in these stands, such as peppers, pickles, grains (beans and corn), condiments (saffron, cilantro), liqueur, cachaça (a fermented or distilled Brazilian liquor made of sugarcane juice), bottled natural medicines, mango, araticum fruit, tamarind, and milk of mangaba fruit, which increase profit. Most owners of stands showed interest in selling products such as pequi chocolate candy, dehydrated pequi, pequi jam, and pequi popsicles. The difficulty in meeting all of the requirements of public health surveillance, the high price of some products and, therefore, lower chances of selling them, and also the difficulty in manufacturing high quality products, discourage vendors from diversifying the range of processed pequi products in their stands. 


\subsection{Pequi used in refined cuisine in the capital - Belo Horizonte}

Out of the 53 typical Minas Gerais food restaurants listed for $\mathrm{BH}$, nine use pequi in their recipes, only five of which volunteered to provide more detailed information on its use. All five of these restaurants offer the traditional rice with pequi, both as self-service food and as table service. Pickled pulp, oil, and toasted flour are associated with other ingredients in composing the recipes. Only one restaurant offered recipes (table service) with pequi throughout the year. One of these recipes is a traditional rice with pequi shavings dish, accompanied by a sun-dried steak stroked with pequi oil. The products are bought at grocery stores in Belo Horizonte, Contagem (CeasaMinas), and Montes Claros. The amount bought in a year varies according to the demand for the dishes, and there is no difficulty in acquiring the product and its subproducts (Table 3).

Table 3. Pequi used in recipes available in five typical Minas Gerais food restaurants in Belo Horizonte. Origin of the products, quantity purchased, location of purchase, and time of product acquisition.

\begin{tabular}{|c|c|c|c|c|}
\hline Dishes & $\begin{array}{l}\text { Kind of product } \\
\text { purchased }\end{array}$ & Quantity purchased & Location of purchase & $\begin{array}{l}\text { Time of } \\
\text { acquisition }\end{array}$ \\
\hline Rice with pequi & Pequi pit & 16 trays/week & Grocery store & Harvest \\
\hline Rice with pequi & Pequi pit & 1 to $2 \mathrm{~kg}$ per week & Provider & Harvest \\
\hline $\begin{array}{l}\text { Rice with pequi shavings and sun-dried steak } \\
\text { stroked with pequi oil }\end{array}$ & Pickled pulp & $\begin{array}{c}300 \text { glasses of } 500 \mathrm{~g} \text { per } \\
\text { year }\end{array}$ & Farmer & Harvest \\
\hline Rice with pequi and pequi liqueur & Pickled pulp & $10 \mathrm{~kg}$ every three months & Cooperjap $^{*}$ & 3 times a year \\
\hline Rice with pequi and pequi dried flour & Pequi pit & 4 trays/week & $\begin{array}{l}\text { Northern Minas } \\
\text { Gerais producer }\end{array}$ & Harvest \\
\hline
\end{tabular}

* Cooperative of Rural Producers and Pequi Collectors of Japonvar, Minas Gerais, Brazil.

Two restaurants offered special dishes made from pequi, one of which was small pickled pequi pits made by the owner. Profit is low, as the dish is offered as a means to please customers who want to try pequi at home.

\subsection{Considerations regarding the Pontinha quilombola community, income generation and commercialization of pequi and its products}

Conciliation between income generation and conservation of NTFPs is a clear possibility for Pontinha through sustainable extractivism, processing and commercialization of pequi. Such conciliation has been documented by other studies developed in Japonvar and Januária in the North Region of Minas Gerais, through the sales of pequi (Caryocar brasiliense), cagaita (Eugenia dysenterica), and butiá (Butia capitata) (Afonso et al., 2015; Freitas \& Ribeiro, 2013); in the state of Maranhão through the sales of buriti (Mauritia flexuosa); and also in the community of El Terrero, Mexico, where the income obtained from the commercialization of blueberries (Rubus spp.) and tila flowers (Ternstroemia lineata) is significant (Marshall \& Newton, 2003).

Pequi has been used in the Pontinha community in the preparation of sweet and salty dishes, and as liqueur and soap, with the latter having little commercial use. Interest was also expressed in larger scale processing and collective sales (Pinto et al., 2016). Indeed, processing and commercialization of pequi in Pontinha has begun as a result of the development of "Projeto Pequi" of Universidade Federal de Minas Gerais.

The municipality where Pontinha community is located has great potential for pequi extractivism, given its important role as a provider to CeasaMinas in Greater BH. Other establishments surveyed in this study also represent opportunities for the distribution of future production, as do access to the School Feeding Program and the Food Acquisition Program. Another favorable point is that pequi is abundant in the quilombola territory, that is, there is no need for extraction in private properties, which may avoid conflicts with farmers, a recurring situation in extractivist activities.

The creation and maintenance of a community organization with work based on socio-biodiversity products is also viable provided that markets for these products are ensured. An environment of cooperation and collective decision-making process is important for promoting group cohesion. The development of a management plan with people from the community who are interested in using pequi as an alternative source of work and income constitutes one of the initial steps of the collective dynamics of production. Thus, studies have been developed, including an ethnoecological study and an ecological study, on the abundance and productivity of pequi producers within the territory of the Pontinha community (Pinto et al., 2016). This information will serve as a foundation for discussions with producers about the 
best forms of extraction, processing, and commercialization of pequi, considering fruit availability and possible viable locations for distribution. However, community organizations are procedural and slow, and must be in consonance with the involvement and reality of their members, and their potentials and difficulties.

In many regions of the Brazilian Cerrado, the production chains of NTFPs remain strong and in advanced stages of consolidation, such as the pequi chain in the North Region of Minas Gerais. This has guaranteed income generation for family farmers and traditional communities while also preserving the Cerrado, as documented by the study of Afonso et al. (2015). Thus, the dissemination of information concerning the dynamics of the pequi commercialization in the Belo Horizonte Metropolitan Region and Central Region of Minas Gerais will make it easier to understand and outline the pequi production chain in these regions and, therefore, guarantee the incorporation of family farmers and rural communities in this process, such as the community of Pontinha.

\section{CONCLUSIONS}

The region in which the Pontinha quilombola community is inserted has the potential for the extraction, processing and commercialization of pequi and its derivatives. This potential is further enhanced by the opportunity of supplying large volumes of this fruit to the CeasaMinas in Greater BH among other commercial establishments considered in this study. This diversity of possibilities for the commercialization of pequi collected in Pontinha, both in natura fruit and processed fruit, is a strategic advantage for the sustainability of commercial activity. Communities, such as Pontinha, that have pequi extractivism as a vocation, can make their harvest plans and use the extractivism of this native fruit as an important source of income.

This study also reinforces the commercial use of pequi as an alternative for the maintenance of the Cerrado biome by reducing vegetal suppression, while at the same time generating income for rural communities and enhancing their traditional practices. In this way, it is also possible to ensure the necessary socio-environmental conditions required for the social reproduction characteristic of ethnically different communities, such as quilombolas, and promote quality of life and health. Finally, it is evident that public policies that encourage the sustainable use of pequi and family agriculture can, if properly developed, encourage rural development by combining social organization with the conservation of the Cerrado and its fruits.

\section{ACKNOWLEDGEMENTS}

We thank the financing of Fundação de Amparo à Pesquisa do Estado de Minas Gerais, Pró-Reitoria de Extensão of Universidade Federal de Minas Gerais (Proex/UFMG), Ministério da Educação, Programa de Apoio à Extensão Universitária (ProExt/MEC) e Programa de Pós Graduação em Ecologia, Conservação e Manejo da Vida Silvestre (UFMG). And especially to the Pontinha community by the trust and partnership.

\section{SUBMISSION STATUS}

Received: 26 Oct. 2017

Accepted: 3 Jan. 2019

Associate editor: Vanessa Maria Basso

(D) 0000-0003-3141-2262

\section{CORRESPONDENCE TO}

\section{Luiza Helena Pedra da Silva}

Universidade Federal dos Vales do Jequitinhonha e Mucuri (UFVJM), Rodovia MGT 367, km 583, 5.000, Alto da Jacuba, CEP 39100-000, Diamantina, MG, Brasil

e-mail: luiza.pedra@gmail.com

\section{FINANCIAL SUPPORT}

Fundação de Amparo à Pesquisa do Estado de Minas Gerais (Grant/Award number: APQ-02423-12); Pró-Reitoria de Extensão of Universidade Federal de Minas Gerais; Programa de Apoio à Extensão Universitária (Proext 2013/MEC/Sesu).

\section{REFERENCES}

Adams C, Munari LC, Van Vliet N, Murrieta RSS, Piperata BA, Futemma $\mathrm{C}$ et al. Diversifying incomes and losing landscape complexity in Quilombola shifting cultivation communities of the Atlantic rainforest (Brazil). Human Ecology 2013; 41(1): 119-137. 10.1007/s10745-012-9529-9

Afonso SR. A política pública de incentivo à estruturação da cadeia produtiva do pequi (Caryocar brasiliense) [dissertation]. Brasília: Universidade de Brasília; 2012.

Afonso SR, Ângelo H, Almeida AN. Caracterização da produção de pequi em Japonvar, MG. Revista Floresta 2015; 45(1): 49-56. 10.5380/rf.v45i1.33987

Aquino FG, Ribeiro JF, Gulias APSM, Oliveira MC, Barros CJS, Hayes KM et al. Uso sustentável das plantas nativas do Cerrado: oportunidades e desafios. In: Parron LM, Aguiar LMS, Duboc E, Oliveira-Filho EC, Camargo AJA, Aquino FG, editors. Cerrado: desafios e oportunidades para o desenvolvimento sustentável. Brasília: Embrapa; 2008. p. 95-124.

Arnold JEM, Ruiz-Pérez M. Can non-timber forest products match tropical forest conservation and development objectives? Ecological Economics 2001; 39(3): 437-447. 10.1016/S0921-8009(01)00236-1 
Avidos MFD, Ferreira LT. Frutos dos Cerrados: preservação gera muitos frutos. Biotecnologia, Ciência \& Desenvolvimento 2000; 3(15): 36-41

Bailey K. Methods of social research. 4th ed. New York: The Free Pass; 2008.

Becker BK. Revisão das políticas de ocupação da Amazônia: é possível identificar modelos para projetar cenários? Parcerias Estratégicas 2001; 12: 135-159.

Brasil. Lei n. 10.186, de 12 de fevereiro de 2001. Diário Oficial da República Federativa do Brasil, Brasília, DF (2001a Feb. 14); Sec. 1: 3.

Brasil. Decreto n. 3.991, de 30 de outubro de 2001. Diário Oficial da República Federativa do Brasil, Brasília, DF (2001b Oct. 31); Sec. 1: 3.

Brasil. Decreto n. 5.996, de 20 de dezembro de 2006. Diário Oficial da República Federativa do Brasil, Brasília, DF (2006 Dec. 21); Sec. 1: 2.

Brasil. Decreto n. 6.040, de 7 de fevereiro de 2007. Diário Oficial da República Federativa do Brasil, Brasília, DF (2007 Feb. 8); Sec. 1: 316-317.

Brasil. Portaria Interministerial n. 239, de 21 de julho de 2009. Diário Oficial da República Federativa do Brasil, Brasília, DF (2009a July 22); Sec. 1: 103-104.

Brasil. Lei n. 11.947, de 16 de junho de 2009. Diário Oficial da República Federativa do Brasil, Brasília, DF (2009b June 17); Sec. 1: 2-4.

Brasil. Portaria Interministerial n. 539, de 12 de novembro de 2009. Diário Oficial da República Federativa do Brasil, Brasília, DF (2009c Nov. 16); Sec. 1: 8.

Brasil. Decreto n. 7.775, de 5 de julho de 2012. Diário Oficial da República Federativa do Brasil, Brasília, DF (2012 July 5); Sec. 1: 3-6.

Cândido PA, Malafaia GC, Rezende ML. A exploração do pequi na região norte de Minas Gerais: abordagem por meio do Sistema Agroalimentar Localizado. Revista IDeAS: Interfaces em Desenvolvimento, Agricultura e Sociedade 2012; 5(2): 118-138.

Carrazza L, Ávila JCC. Manual tecnológico de aproveitamento integral do fruto do pequi. Brasília: Instituto Sociedade Natureza e População; 2010.

Carrazza L, Figueiredo I. Cerrado que te quero vivo! Produtos e meios de vida sustentáveis apoiados pelo Programa de Pequenos Projetos Ecossociais (PPP-ECOS). Brasília: Instituto Sociedade, População e Natureza; 2010.

Centrais de Abastecimento de Minas Gerais S.A. - CeasaMinas. Informações de mercado [Internet]. [2014?] [cited 2014 Oct.10]. Available from: https://bit.ly/2OwE0g8

Crúzio HO. Como organizar e administrar uma cooperativa: uma alternativa para o desemprego. 2nd ed. Rio de Janeiro: Ed. FGV; 2001.

Dembner SA. Editorial: learning to see the forest through the trees. Unasylva 1991; 42(165): 2.

Drumond MA, Guimarães AQ, El BizriHR, Giovanetti LC, Sepúlveda DG, Martins RP. Life history, distribution and abundance of the giant earthworm Rhinodrilus alatus RIGHI 1971: conservation and management implications. Brazilian Journal of Biology 2013; 73(4): 699-708. 10.1590/S1519-69842013000400004

Drumond MA, Guimarães AQ, Silva RHP. The role of local knowledge and traditional extraction practices in the management of giant earthworms in Brazil. PLoS ONE 2015; 10(4): e0123913. 10.1371/journal.pone.0123913

Enders BA, Gorchov DL, Berry EJ. Sustainability of a non-timber forest product: effects of alternative leaf harvest practices over 6 years on yield and demography of the palm Chamaedorea radicalis. Forest Ecology and Management 2006; 234(1-3): 181-191. 10.1016/j. foreco.2006.07.020

Felfili JM, Silva MC Jr, Sevilha AC, Fagg CW, Walter BMT, Nogueira PE, Rezende AV. Diversity, floristic and structural patterns of Cerrado vegetation in Central Brazil. Plant Ecology 2004; 175(1): 37-46. 10.1023/B:VEGE.0000048090.07022.02

Freitas CS, Ribeiro EM. Experiências de comercialização agroextrativa dos agricultores familiares do Rio dos Cochos, Januária/Cônego Marinho-MG. Organizações Rurais e Agroindustriais 2013; 15: 411-424.

Instituto Brasileiro de Geografia e Estatística - IBGE. Produção da extração vegetal e da silvicultura. Rio de Janeiro; 2010. v. 25.

Instituto Brasileiro de Geografia e Estatística - IBGE. Produção da extração vegetal e da silvicultura. Rio de Janeiro; 2011. v. 26.

Instituto de Terras do Estado de São Paulo - ITESP. Negros do Ribeira: reconhecimento étnico e conquista do território. Cadernos do ITESP 2000; 3.

José P. A vitória do pequi: como o fruto dourado dos Cerrados vai conquistando o Brasil. Cerne 2007; 15(3): 282-287.

Leite GLD, Veloso RVS, Zanuncio JC, Fernandes LA, Almeida CIM. Phenology of Caryocar brasiliense in Brazilian Cerrado region. Forest Ecology and Management 2006; 236(2-3): 286-294. 10.1016/j. foreco.2006.09.013

Lüdke M, André M. Pesquisa em educação: abordagens qualitativas. São Paulo: EPU; 1986.

Luengo RFA, Camargo-Filho W, Jacomino AP. Participação do custo da embalagem na composição do custo de produção e do preço de atacado do tomate de mesa. Horticultura Brasileira 2003; 21(4): 719-721. 10.1590/S0102-05362003000400030

Magalhães RM. A cadeia produtiva da amêndoa do baru (Dipteryx alata Vog.) no Cerrado: uma análise da sustentabilidade da sua exploração. Ciência Florestal 2014; 24(3): 665-676. 10.1590/1980509820142403014

Marshall E, Newton AC. Non-timber forest products in the community of El Terrero, Sierra de Manantlán Biosphere Reserve, México: is their use sustainable? Economy Botany 2003; 57(2): 262-278. 10.1663/0013-0001(2003)057[0262:NFPITC]2.0.CO;2

Minas Gerais. Lei n. 13.965, de 27 de julho de 2001. Minas Gerais Diário do Executivo, Belo Horizonte (2001 July 28): 5.

Minas Gerais. Lei n. 16.296, de 1 de agosto de 2006. Minas Gerais Diário do Executivo, Belo Horizonte (2006 Aug. 2): 1.

Myers N, Mittermeier RA, Mittermeier CG, Fonseca GAB, Kent J. Biodiversity hotspots for conservation priorities. Nature 2000; 403: 853-858. 10.1038/35002501

Nogueira MCR, Fleischer SR. Entre a tradição e modernidade: potenciais e contradições da cadeia produtiva agroextrativista no Cerrado. Estudos Sociedade e Agricultura 2005; 13(1): 125-157. 
Oliveira CS, Gonçalves LEN, Coutinho MP, Peixoto N, Gatto A. Aspectos socioambientais da comercialização de pequi em Goiás. Floresta e Ambiente 2017; 24: e00058213. 10.1590/2179-8087.058213

Peters CM, Gentry AH, Mendelsohn RO. Valuation of an Amazonian rainforest. Nature 1989; 339(6227): 655-656. 10.1038/339655a0

Pinto LCL, Morais LMO, Guimarães AQ, Almada ED, Barbosa PM, Drumond MA. Traditional knowledge and uses of the Caryocar brasiliense Cambess. (Pequi) by "quilombolas" of Minas Gerais, Brazil: subsidies for sustainable management. Brazilian Journal of Biology 2016; 73(6): 511-519. 10.1590/1519-6984.22914

Rezende ML, Cândido PA. Produção e comercialização de frutos do Cerrado em Minas Gerais. Revista de Política Agrícola 2014; 23(3): 81-86.

Schmidt IB, Figueiredo IB, Scariot A. Ethnobotany and effects of harvesting on the population ecology of Syngonanthus nitens (Bong.) ruhland (Eriocaulaceae), from Jalapão region, central Brazil. Economic Botany 2007; 61(1): 73. 10.1663/0013-0001(2007)61[73:EAEOHO]2.0.CO;2

Silva CEM. Ordenamento territorial no Cerrado brasileiro: da fronteira monocultora a modelos baseados na sociobiodiversidade. Desenvolvimento e Meio Ambiente 2009; 19: 89-109. 10.5380/dma. v19i0.16407

Ticktin T. The ecological implications of harvesting non-timber forest products. Journal of Applied Ecology 2004; 41(1): 11-21. 10.1111/j.1365-2664.2004.00859.x

Wadt LHO, Kainer KA, Staudhammer CL, Serrano ROP. Sustainable forest use in Brazilian extractive reserves: natural regeneration of Brazil nut in exploited populations. Biological Conservation 2008; 141(1): 332-346. 10.1016/j.biocon.2007.10.007

Wickens GE. Management issues for development of non-timber forest products. Unasylva 1991; 42(165): 3-8. 